\title{
VARYING A V BLOCK COMPLICATING SNAKE BITE - A CASE REPORT
}

Vikas L ${ }^{1}$, Riyaz Ahmed ${ }^{2}$

\section{HOW TO CITE THIS ARTICLE:}

Vikas L, Riyaz Ahmed. "Varying A V Block Complicating Snake Bite - A Case Report”. Journal of Evolution of Medical and Dental Sciences 2014; Vol. 3, Issue 07, February 17; Page: 1713-1717,

DOI: $10.14260 /$ jemds/2014/2047

ABSTRACT: Snake venom toxicities comprise mainly bleeding disorders and nephrotoxicity. Cardiotoxicity is a rare manifestation of snake bite. We describe the case of a previously healthy 23year-old man who developed coagulopathy and AV node dysfunction following snake bite. Electrocardiography showed all variations of AV conduction dysfunction. This is the first account of $\mathrm{AV}$ node dysfunction caused by a snake bite with cardiotoxicity presenting as atrioventricular block.

KEYWORDS: Sick sinus syndrome, snake bites, AV conduction blocks, neurotoxicity, AV dissociation.

INTRODUCTION: Snake bite is a common problem in rural areas of Asia, and the cause of several thousand deaths each year. Snake bite is usually characterized by a local tissue reaction, hemorrhagic manifestations, and nephrotoxicity; cardiac involvement is rare. There are number of case reports regarding myocarditis and myocardial infarction ${ }^{1}$ following snake bite but not many cases have been described with the involvement of the conducting system of the heart. Here we present a case with AV conduction abnormality following snake bite.

Case report A 23 year old male presented to emergency ward 24 hours after snake bite with history of blurring of vision, diplopia and decreased urine output. On admission his pulse was 54 beats/min, irregularly irregular. BP-120/70 mm of Hg, RR-14 breaths/min. On local examination fang mark was present over left $2^{\text {nd }}$ toe with no signs of local reaction and systemic manifestation of envenomation. Investigations done on the same day revealed ECG with normal rhythm(fig 1), troponin T - negative, serum electrolytes were normal, WBC count- 26,700 cells $/ \mathrm{mm}^{3}$, blood urea- 62 $\mathrm{mg} / \mathrm{dl}$, S.creatinine- $2.5 \mathrm{mg} / \mathrm{dl}$, platelet count- 50,000 cells $/ \mathrm{mm}^{3}$, WBCT> 20 mins (table 2). The patient was immediately started on IV fluids, ASV, antibiotics and analgesics. Inspite of giving ASV 10 hours later he complained of worsening of diplopia and patient developed tachypnea, cyanosis, ptosis, muscle weakness, fasciculations all suggestive of neuromuscular manifestations of envenomation. He was shifted to MICU and was intubated.

Repeat ECG (after 6 hrs.) showed 1st degree AV block (fig 2). 24 hours after admission patient developed hypotension and was started on inotropic support and steroid. ECG showed tachycardia, non-specific ST, T wave changes with AV dissociation (fig 3).On the $2^{\text {nd }}$ day he was hemodynamically stable and inotropic support was discontinued. His neuromuscular weakness also improved and was extubated. ECG showed 1st degree AV block with persistence of non-specific ST, T wave changes (fig 4). ECG repeated on $4^{\text {th }}-11^{\text {th }}$ day showed persistent $2^{\text {nd }}$ degree AV block and he was hemodynamically stable. In view of persistent bradycardia he was started on isoprenaline on $6^{\text {th }}$ day, by $10^{\text {th }}$ day heart rate improved to 93 beats $/ \mathrm{min}$. On the $12^{\text {th }}$ day ECG was normal. Patient was discharged on the $15^{\text {th }}$ day with $\mathrm{HR}$ of 84 beats/ min. On the $1^{\text {st }}$ follow up after 1 week ECG was normal with HR of 84 beats/ $\min ($ fig 5). ECG changes from day of admission till discharge has been described in table 1. 


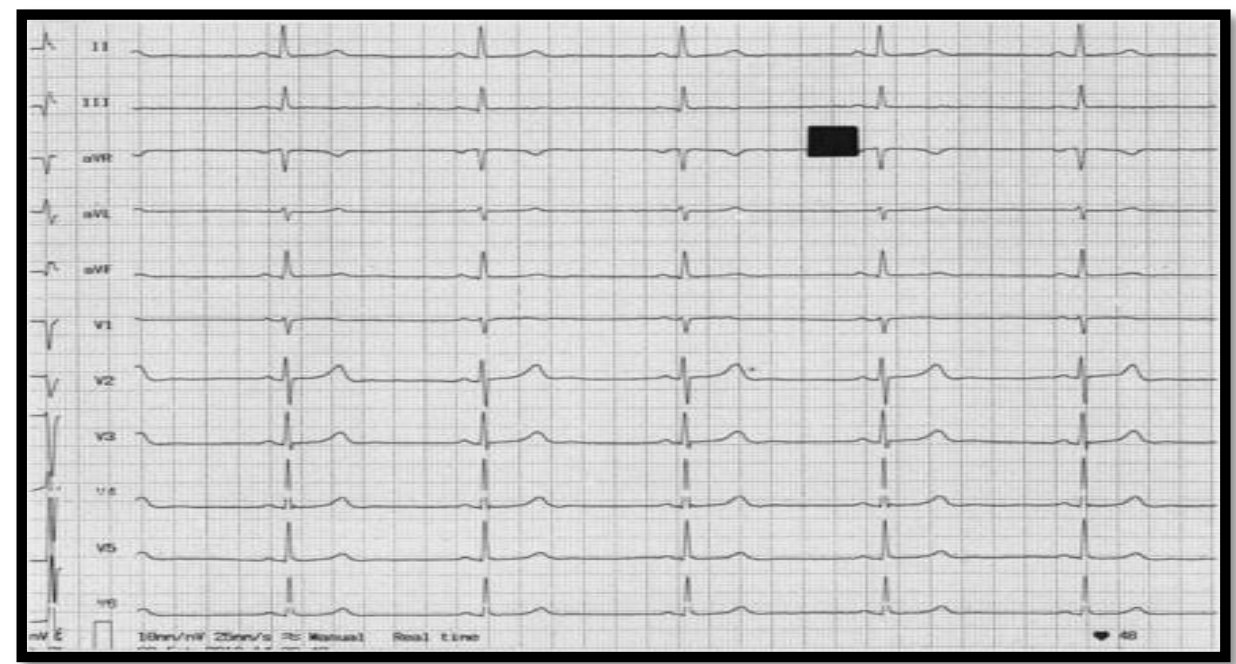

Fig. 1: (at time of admission normal rate and rhythm)



Fig. 2: (Day 1- 10 hrs after admission showing 1st degree AV block)

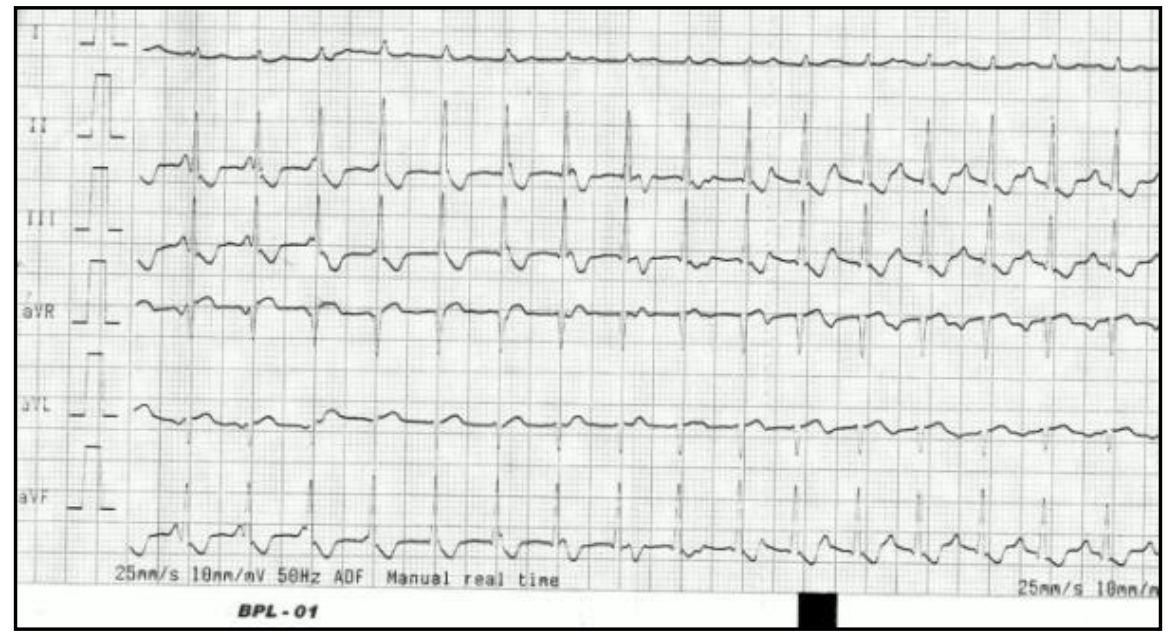

Fig. 3: On Day 2 showing AV dissociation 


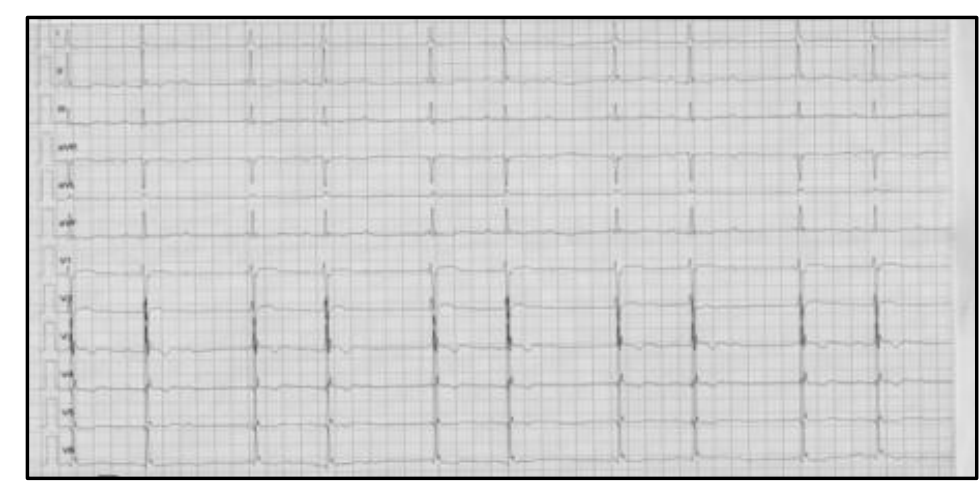

Fig. 4: (Day 5 showing $2^{\text {nd }}$ degree AV block- Mobitz type I)

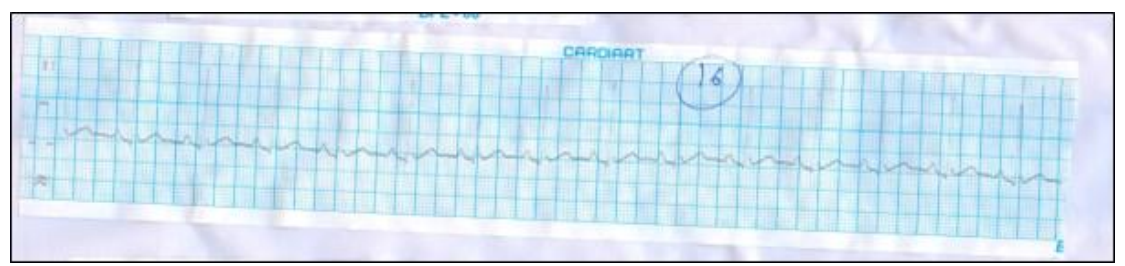

Fig. 5: Day 14 showing normal ECG

\begin{tabular}{|c|c|c|c|c|}
\hline Day & $\mathrm{HR} / \mathrm{min}$ & PR interval & ST-T wave changes & Conclusion \\
\hline On admission & 50 & Normal & No changes & normal \\
\hline $6 \mathrm{hrs}$ & 40 & Varying & $\mathrm{ST} \uparrow \mathrm{V} 2$ & $\begin{array}{l}\text { Varying } 2^{\text {nd }} \text { degree } \\
\text { block type I }\end{array}$ \\
\hline $10 \mathrm{hrs}$ & 65 & $0.28 \mathrm{sec}$ & $\begin{array}{l}\text { ST } \uparrow \mathrm{V} 1, \mathrm{~V} 2, \mathrm{~T} \text { inversion } \\
\mathrm{V} 1, \mathrm{~V} 2, \mathrm{~V} 3\end{array}$ & $1^{\text {st }}$ degree AV block \\
\hline $24 \mathrm{hrs}$ & 150 & $\begin{array}{r}\text { Progressive } \\
\text { shortening }\end{array}$ & $\begin{array}{l}\text { ST } \downarrow \& \text { T inversion } \\
\text { V1, V2,V3 }\end{array}$ & $\begin{array}{l}\text { AV dissociation,? } \\
\text { Myocarditis }\end{array}$ \\
\hline $48 \mathrm{hrs}$ & 107 & $0.24 \mathrm{sec}$ & $\begin{array}{l}\mathrm{ST} \uparrow \mathrm{V} 1, \mathrm{~V} 2, \mathrm{ST} \downarrow \& \\
\mathrm{~T} \text { inversion II,III,avF,V3-V6 }\end{array}$ & $1^{\text {st }}$ degree AV block \\
\hline $4^{\text {th }}$ day & 53 & $0.12 \mathrm{sec}$ & $\begin{array}{l}\text { ST coving V2, } \\
\text { T inversion V3,V4 }\end{array}$ & $\begin{array}{l}? 2^{\text {nd }} \text { degree AV } \\
\text { block } 2: 1\end{array}$ \\
\hline $5^{\text {th }}$ day & 50 & Varying & $\begin{array}{l}\text { ST } \uparrow \mathrm{V} 1, \mathrm{~V} 2, \mathrm{~T} \text { inversion } \\
\mathrm{II}, \mathrm{III}, \mathrm{avF}, \mathrm{V} 3-\mathrm{V} 6\end{array}$ & $\begin{array}{l}2^{\text {nd }} \text { degree AV block } \\
\text { type } 1,3: 2\end{array}$ \\
\hline $8^{\text {th }}$ day & 50 & Varying & $\begin{array}{l}\text { T inversion II,III, } \\
\text { avF,V1-V6 }\end{array}$ & $\begin{array}{l}\text { Varying } 2^{\text {nd }} \text { degree } \\
\text { block } 3: 2,2: 1,4: 3\end{array}$ \\
\hline $9^{\text {th }}$ day & 60 & Varying & $\begin{array}{l}\text { ST } \uparrow \text { V2, T inversion II,III, } \\
\text { avF,V3-V6 }\end{array}$ & $\begin{array}{l}\text { Varying } 2^{\text {nd }} \text { degree } \\
\text { block } 3: 2,2: 1\end{array}$ \\
\hline $10^{\text {th }}$ day & 93 & Varying & ST $\uparrow V 1, T$ inversion V2-V4 & $\begin{array}{l}\text { Varying } 2^{\text {nd }} \text { degree } \\
\text { block } 5: 4,4: 3\end{array}$ \\
\hline $11^{\text {th }}$ day & 60 & Varying & $\begin{array}{l}\text { ST } \uparrow V 2, T \text { inversion } \\
\text { V1,V2,V3 }\end{array}$ & $\begin{array}{l}2^{\text {nd }} \text { degree AV block } \\
\text { type } 14: 3\end{array}$ \\
\hline $12^{\text {th }}$ day & 90 & $0.16 \mathrm{sec}$ & $\begin{array}{l}\text { ST } \uparrow V 2, T \text { inversion } \\
\text { V1,V2,V3 }\end{array}$ & Normal \\
\hline $14^{\text {th }}$ day & 84 & $0.16 \mathrm{sec}$ & Normal & Normal \\
\hline
\end{tabular}




\begin{tabular}{|c|c|c|c|c|c|c|}
\hline Day & $\begin{array}{c}\text { Total } \\
\text { Count }- \\
\text { cells } / \mathrm{mm}^{3}\end{array}$ & $\begin{array}{c}\text { Blood } \\
\text { urea } \\
\mathrm{mg} / \mathrm{dl}\end{array}$ & $\begin{array}{c}\text { S.creatinin } \\
\text { e mg/dl }\end{array}$ & $\begin{array}{c}\text { S.potassium- } \\
\mathrm{meq} / \mathrm{L}\end{array}$ & $\begin{array}{c}\text { Platelet } \\
\text { count- } \\
\text { cells/mm }\end{array}$ & WBCT-min \\
\hline 1 & 26700 & 62 & 2.5 & 4.49 & 50000 & $>20$ \\
\hline 2 & 28100 & 65 & 1.3 & 4.8 & 70000 & $>20$ \\
\hline 3 & 31700 & 40 & 0.8 & 4.43 & 141000 & $<20$ \\
\hline 4 & 27800 & 42 & 0.8 & 3.57 & 180000 & $<20$ \\
\hline 12 & 6400 & 39 & 0.8 & 3.84 & 190000 & $<20$ \\
\hline \multicolumn{7}{r}{ Table 2: Hematological \& biochemical findings } \\
\end{tabular}

DISCUSSION: Cardiac complications and ECG abnormalities following snake bite has been reported number of times but not many case reports with involvement of conduction system of the heart has been described. In this case species of snake has not been identified and troponin $\mathrm{T}$ was negative. Varying AV block was observed from day1 to day 11 and ECG became normal on day 12 .

ECG abnormalities or involvement of the myocardium has been observed following envenomation by a no of different species of snakes including viper berus, atractaspis engaddensis, Echis ocellatus and Calloselasma rhodostoma.

Explanation for ECG changes in our case might be because of various mechanisms. In a prospective study conducted by David G et $\mathrm{al}^{2}$ in Port Mores General hospital in PapuaNew Guinea between march 1990 and june1992 they studied ECG's of 139 patients envenomated by Elapid snakes in that 76 patints had ECG abnormalities,commonest abnormalities were septal $\mathrm{T}$ wave invertion and bradycardia including AV block. Bradycardia/10 AV block were seen in 2 of the taipan envenomation and $2^{0} \mathrm{AV}$ blockin one case bitten by death adder. ECG abnormalities are most likely to have been caused by a direct toxic effect of a venom component either on the heart or on the innervation of the heart.In Taipan bites taicatoxin a CCB might be responsible for the ECG abnormality. ${ }^{2}$

In a study done by Nayak KC et al in SP Medical College,Bikaner they studied 30 cases of snake bite cardiotoxicity was seen in $30 \%$ in that $\mathrm{AV}$ block in $3.3 \%$ only. ${ }^{3}$

Tony JC et al reported a case of acute MI complicating snake bite in a 47 year old man.It was presumed to be due to sarafotoxin in snake venom having vascular toxic effect leading to vasospasm in coronary vessels and also delay AVconduction. ${ }^{4}$

Various other mechanisms have been suggested -directly acting cardiotoxin ${ }^{5}$, myotoxin causing cardiac muscle damage, ${ }^{6}$ coronary vasospasm, ${ }^{7}$ electrolyte disturbance, ${ }^{8}$ severe hypotension ${ }^{9}$ and disturbance of autonomic innervation of the heart.

CONCLUSION: This case report describes the fatal outcome of snake bite in a $23 \mathrm{yr}$. old male due to cardiotoxic manifestation of snake bite. Toxic myocarditis seems unlikely to be the cause of the ECG changes because cardiac enzymes were not elevated and there were no findings suggestive of myocarditis on ECG or echocardiography. One should consider a direct toxic effect of venom on the sinus node. It is believed that snake venom modifies the electrophysiological properties of the cardiac cell membrane, and can have a profound effect on impulse generation and conduction. However, the exact pathophysiology is not known. All physicians should be prepared for prompt treatment of even such a rare manifestation of snake bite. This case also suggests that victims may need prolonged 
cardiac monitoring even when the acute phase is over. Studies are required to elucidate the effect of snake venom on the electrophysiological properties of the cardiac cell membrane.

\section{REFERENCES:}

1. Aravanis $\mathrm{C}$, Ioannidis $\mathrm{P}, \mathrm{Ktenas} \mathrm{J.} \mathrm{Acute} \mathrm{myocardial} \mathrm{infarction} \mathrm{and} \mathrm{cerebrovascular} \mathrm{accident} \mathrm{in} \mathrm{a}$ young girl after a viper bite. Br Heart J. 1982; 47: 500-503.

2. David lallo,Andrew J Trevett,Nneka N wokolo, Ian F Laurenson, Sirus Naraqi,Isikevau, et al. ECG abnormalities in patients bitten by taipans and other elapid snakes in papua New Guinea. American Journal of Tropical Medicine and Hygiene,52, 525-531.

3. Nayak KC, Jain AK, Sharada DP, Mishra SN . Profile of cardiac complications of snake bite. Indian Heart Journal 1990 may-jun 42(3)185-8.

4. Tony JC,Bhat R .Acute Myocardial infarction following snake bite.Trop doct 1995;3:137.

5. Nayler,W.G.,Sullivan,A.T., Dunnet,J., Slade, A . M. \& Trethewie,E .R.(1976).The effect of a cardiotoxic component of the venom of the indian cobra(naja nigricollis) on the subcellular structure and function of heart muscle.Journal of Molecular and cellular Cardiology,8,341-360.

6. Rowlands,J.B, Mastaglia,F.L, Kakales,B.A, \& Hainsworth,D. (1969). Clinical \& pathological aspects of a fatal case of mulga (pseudechis australis) snake bite. Medical journal of Aurstralia, i,226-230.

7. Tibbak,J.,Sutherland,S.k, Rivere,R.A \& Masei,P.P.(1992). The cardiovascular \& haematological effects of purified prothrombin activator from the common brown snake (pseudogenic t) \& their antagonism with heparin. Anaesthesia \& Intensive care 20, 28-32.

8. Reid,H.A (1961). Myoglobinuria \& sea-snake poisoning. British Medical Journal, i,1284-1289.

9. Myint-Levin, Warrell,D.A, Phillips,R.E, Tin-Nu, Swe Tunpe \& Mauy-Mauy Lay (1985). Bites of Russel viper in Burma: Heaomostatic, vascular, renal disturbance \& response to treatment. Lancet, ii, 1259-1264.

\section{AUTHORS:}

1. Vikas L.

2. Riyaz Ahmed

\section{PARTICULARS OF CONTRIBUTORS:}

1. Assistant Professor, Department of Medicine, Mysore Medical College and Research Institute.

2. Senior Resident, Department of Medicine, Mysore Medical College and Research Institute.

\section{NAME ADDRESS EMAIL ID OF THE CORRESPONDING AUTHOR:}

Dr. Vikas L, Door - 11, $9^{\text {th }}$ Main, $6^{\text {th }}$ cross, Brindavan First Stage, Mysore - 570020.

E-mail: vikilaxman@gmail.com

Date of Submission: 13/12/2013.

Date of Peer Review: 14/12/2013

Date of Acceptance: 27/01/2014.

Date of Publishing: 13/02/2014. 